\title{
THE ENGLISH CHILDREN AND FAMILIES ACT 2014
}

\author{
Andrew Bainham* and Stephen Gilmore ${ }^{* *}$
}

Parts I and II of the Children and Families Act 2014 may appear to make little change to English child law, largely amending existing statutes with provisions of a procedural and evidential flavour. Yet, as this article explains, it is deeply ideological legislation with roots in the Narey Report on adoption and the Family Justice Review. The article examines the background to the legislation and shows how, in the private law, statutory language was used to convey an "official" message concerning the importance of both separating parents remaining "involved" in their children's lives. This resulted in enactment of a presumption of parental involvement in court decision making, and a more neutral "child arrangements order", replacing the supposed polarising duality of "residence" and "contact" orders with little more than a change of terminology and the disadvantage of greater complexity. The ideology underpinning the public law provisions is to encourage adoption by speeding up the process, getting children through care proceedings as quickly as possible and into adoptive families. This thinking may appear to clash with recent jurisprudence of the higher courts which has emphasised that adoption is a "last resort" in child protection, and that significant human rights issues arise. The analysis highlights a key question, cutting across the public and private law provisions, namely whether the 2014 Act dilutes English law's long-standing commitment to the paramountcy of child welfare.

\section{INTRODUCTION}

Writing in 2006, ${ }^{1}$ Bill Atkin said of the then recent Care of Children Act 2004 that its title was something of a misnomer. The legislation did not deal with child care issues in their entirety, and most notably, child protection issues in New Zealand remained governed by the earlier Children, Young Persons, and Their Families Act 1989.

* Barrister at St Philips Chambers, Emeritus Reader in Family Law and Policy, University of Cambridge. Andrew was editor of the International Survey of Family Law from 1994-2006 during which period he greatly appreciated the regular, erudite contributions of Bill Atkin on developments in New Zealand. He was therefore delighted when Bill assumed the editorship in 2006 which has enabled the Survey to go on from strength to strength.

** Professor of Family Law, King's College London.

1 Bill Atkin "New Zealand: Landmark Family Legislation" in Andrew Bainham (ed) The International Survey of Family Law (Jordan Publishing, Bristol, 2006) 305 at 306. 
Much the same can be said of the deceptively entitled Children and Families Act 2014 (UK) (the 2014 Act), which made it to the statute book in England last year. While the Act apparently ranges widely over the private law, the public law, adoption, special educational needs, childcare, the children's commissioner, parental leave, antenatal care and flexible working, it is in no sense a comprehensive family code. ${ }^{2}$ Indeed, so far as pts I (Adoption and Children Looked After by Local Authorities) and II (Family Justice) are concerned, the 2014 Act merely dips into the existing statutory framework under the Children Act 1989 (UK) (the 1989 Act) and the Adoption and Children Act 2002 (UK), largely just amending those statutes. Such changes as it does make, especially in the public law, have a strong procedural and evidential flavour, perhaps masking the ideological shifts which underpin these provisions. This is the nature of the difficulty for anyone seeking to understand the new English legislation. At first blush it appears to make little change to the substantive private and public law, or adoption. Yet, as we shall seek to show in this article, in truth this is a deeply ideological piece of legislation which has its roots in the Narey Report on adoption $^{3}$ and the Family Justice Review. ${ }^{4}$

\section{THE PRIVATE LAW}

\section{A Background}

The private law provisions of pt II of the 2014 Act represent a package of reforms attempting to address longstanding debates concerning the courts' approach to adjudicating on post-separation parenting arrangements. ${ }^{5}$ Those dissatisfied with the law claimed that the commonplace practice of awarding the child's residence to one parent - and to the other mere contact with the child - did not adequately value both parents' involvement in the child's life. Hence, it was argued that the law should adopt a norm of shared parenting (put most strongly, a presumption of equal division of the child's time), or at least a presumption of a meaningful ongoing relationship between the child and

2 In this article we are concerned only with pts I and II of the Act which might be seen as its mainstream family law provisions.

3 Martin Narey "The Narey Report on Adoption: Our Blueprint for Britain's Lost Children" The Times (United Kingdom, 5 July 2011).

4 Family Justice Review Panel Family Justice Review: Final Report (Ministry of Justice, November 2011) [Family Justice Review: Final Report]. The recommendations were substantially, though not entirely, accepted by the Government in Ministry of Justice and Department for Education The Government Response to the Family Justice Review: A system with children and families at its heart (February 2012).

5 For an excellent discussion of law and policy development in England and Wales over the last three decades, see Liz Trinder "Climate change? The multiple trajectories of shared care law, policy and social practices" (2014) 26 CFLQ 30 (identifying five phases of evolution, played out via competing policy frames of child welfare and parental rights, and to a lesser extent through the "frames" of "risk" and "resources" (or diversion from courts)). 
the non-resident parent. In the 2000s the issue became highly politicised ${ }^{6}$ and the end of that decade saw the issue in England and Wales examined by the Family Justice Review.

The Government accepted the Family Justice Review's recommendation that "residence orders" and "contact orders" be replaced by a new "child arrangements order", agreeing that "contact" and "residence" had become unhelpfully associated with the idea of losing and winning. ${ }^{7}$

The Family Justice Review (and subsequently the House of Commons Justice Committee) ${ }^{8}$ concluded, however, that there should be no change to the legislative framework by which the courts make decisions concerning post-separation parenting arrangements. ${ }^{9}$ The Family Justice Review was influenced by evaluations of the impact of legislation in Australia. ${ }^{10}$ It was said that the courts' required focus on the benefit to the child of having a meaningful relationship with each parent had been privileged over child safety in some cases, leading to shared-care time arrangements being made even where there were ongoing concerns about family violence or child abuse. ${ }^{11}$ This led the Family Justice Review to conclude that "no legislation should be introduced that creates or risks creating the perception that there is a parental right to substantially shared or equal time for both parents", ${ }^{12}$ which might compromise the guiding principle of the paramountcy of the child's welfare. However, contrary to the informed opinions of the Family Justice Review and the House of Commons Justice Committee (the Justice Committee), the Government wanted an explicit "legislative statement of the importance of children having an ongoing relationship with both their parents after family separation, where that is safe, and in the child's best interests". The statement,

6 Trinder, above n 5; and Helen Rhoades "The Rise and Rise of Shared Parenting Laws: A Critical Reflection" (2002) 19 Can J Fam L 75; Helen Rhoades and Susan B Boyd "Reforming Custody Laws: A Comparative Study" (2004) 18 IJLPF 119; and Richard Collier and Sally Sheldon (eds) Fathers' Rights Activism and Law Reform in Comparative Perspective (Hart Publishing, Oxford, 2006).

7 Ministry of Justice and Department for Education, above n 4. Putting the point more positively, the Law Society of England and Wales suggested that the neutral language was "more likely to focus the court and the parents on the practical arrangements for caring for the child and for the co-operative parenting of that child": see Justice Committee Pre-legislative scrutiny of the Children and Families Bill (4th Report of Session 2012-2013, HC739, December 2012) at [127].

8 Justice Committee Operation of the Family Courts (6th Report of Session 2010-2012, HC518-I, 2011).

9 Children Act 1989 (UK), s 1 (the paramountcy of the child's welfare, guided by a checklist).

10 Family Law Amendment (Shared Parental Responsibility) Act 2006 (Cth).

11 See "Annex G-Helen Rhoades' evidence in relation to shared parenting" in Family Justice Review: Final Report, above n 4, at 315. For discussion of the Australian experience, see Belinda Fehlberg and others "Legislating for Shared Time Parenting After Separation: A Research Review" (2011) 25 IJLPF 318. The Australian Legislature subsequently enacted the Family Law Legislation Amendment (Family Violence \& Other Measures) Act 2011 (Cth) to remedy this concern and to ensure that, in any balancing of factors, safety is given greater weight.

12 "Executive Summary" in Family Justice Review: Final Report, above n 4, at [109]. 
though, was to be "framed to avoid the pitfalls of the Australian experience, in particular that a meaningful relationship is not about equal division of time". ${ }^{13}$

A consultation on proposed legislation swiftly followed, ${ }^{14}$ canvassing four possible models, including the Government's preferred option of a presumption that the welfare of the child will be furthered by the involvement of each parent who can be involved in a way not adverse to the child's safety. ${ }^{15}$ The Government reported that consultation responses showed "a clear preference among those who responded for legislative change", with 52 per cent of respondents who chose an option selecting the Government's preferred option. ${ }^{16}$

\section{$B$ The New Provisions: the Child Arrangements Order and the Presumption of Parental Involvement}

The Government took forward its desired changes to private children law in pt II of the 2014 Act. ${ }^{17}$ Section 12 introduced the new "child arrangements order", defined as an order regulating arrangements relating to any of the following: (a) with whom a child is to live, spend time or otherwise have contact; and (b) when a child is to live, spend time or otherwise have contact with any person. ${ }^{18}$

Section 11 of the 2014 Act $^{19}$ amended s 1 of the 1989 Act to introduce a presumption of parental involvement whenever the court is considering whether to make ${ }^{20}$ a child arrangements

13 Ministry of Justice and Department for Education, above n 4, at [61] and [62].

14 Department for Education Co-operative Parenting Following Family Separation: Proposed Legislation on the Involvement of Both Parents in a Child's Life (13 June 2012).

15 The other options were: a general principle that the child's welfare is likely to be furthered by the fullest possible involvement of each parent; a starting point that the child's welfare is likely to be furthered if each parent is involved; or the court simply having regard to enabling the child concerned to have the best relationship possible with each parent of the child. The consultation made clear that the proposed change was: "categorically not about equality in the time that a child spends with each parent after separation ... Every family and every child's circumstances are different, and the courts will continue to make decisions on that basis." Department for Education, above n 14, at [4.4].

16 Department for Education Cooperative parenting following family separation: proposed legislation on the involvement of parents in a child's life: summary of consultation responses and the Government's response (November 2012).

17 Following pre-legislative scrutiny of, and a Government response to, draft legislation: see Justice Committee, above n 7; and Secretary of State for Education Children and Families Bill 2013: Contextual Information and Responses to Pre-Legislative Scrutiny (Cm 8540, February 2013).

18 Implemented on 22 April 2014.

19 Implemented on 22 October 2014.

20 Or vary or discharge. 
order ${ }^{21}$ which is opposed by any party to the proceedings, or considering whether to make or discharge a parental responsibility order. ${ }^{22}$ Section $1(2 \mathrm{~A})$ provides that in those circumstances a court "is as respects each parent within subsection (6)(a) to presume, unless the contrary is shown, that involvement of that parent in the life of the child concerned will further the child's welfare". Involvement is defined in $\mathrm{s} 1(2 \mathrm{~B})$ to mean "involvement of some kind, either direct or indirect, but not any particular division of a child's time". For the purpose of s 1(2A), a "parent of the child concerned" is within (6)(a) "if that parent can be involved in the child's life in a way that does not put the child at risk of suffering harm" and is to be so treated: ${ }^{23}$

... unless there is some evidence before the court in the particular proceedings to suggest that involvement of that parent in the child's life would put the child at risk of suffering harm whatever the form of the involvement.

\section{Criticism}

\section{Complex drafting and difficulties of interpretation}

The new child arrangements order can be criticised as being little more than a change of terminology, whilst making the existing statute unnecessarily complex, although somewhat paradoxically, contrary to the Government's stated aim, it may also increase the number of shared time arrangements. As Liz Trinder has observed: ${ }^{24}$

Previously, parents seeking to establish their equal status had the prospect of a symbolic shared residence order to fight for. Under the new regime the only outlet for that desire will be in terms of an equal time split rather than a label.

The new terminology has necessitated numerous consequential amendments to the 1989 Act, for example replacing references to a "residence order" with more complex constructions such as "a child arrangements order in which a person is named as the person with whom a child is to live". 25 However, in order to retain the different legal incidents that attached to residence and contact orders respectively, it has been necessary in amending the statute to make clear at various points which type of child arrangements order is being referred to, thus in substance retaining the distinction

21 The presumption applies to the making of any order under s 8 of the Children Act 1989 (UK); that is, also to a specific issue order or a prohibited steps order.

22 An order under s 4(1)(c) or (2A), or s $4 \mathrm{ZA}(1)(\mathrm{c})$ or (5) of the Children Act 1989 (UK) (parental responsibility of parent other than mother).

23 Children Act 1989 (UK), s 6(1)(a) and (b).

24 Trinder, above $\mathrm{n}$, at 49.

25 See Children and Families Act 2014 (UK), sch 2. 
between contact and residence. ${ }^{26}$ The child arrangements order has complicated matters because the nature of the order is no longer immediately apparent from the title of the order: one now needs to interrogate the content of the order to know its general legal consequences.

The new presumption of parental involvement is also an extremely complex construction, which no doubt is likely to require judicial clarification. Commentators have already highlighted potential problems of interpretation.

As the authors have observed elsewhere, the complex drafting appears to admit of the fact that the circumstances in which a parent is defined as being "worthy" of the presumption applying need not necessarily be the circumstances in which the presumption will be applied. ${ }^{27}$ For example, where a court concludes that involvement by indirect contact would not put the child at risk, it seems that the presumption would apply even on an application for direct contact, even though there may be evidence that direct contact would place the child at risk of harm. Of course, the presumption might in such a case be readily rebutted, but the fact remains that the onus would then be on the respondent to provide evidence to rebut it, which might prove problematic, particularly in cases involving litigants in person.

The fact that s 1(2A) applies to applications for parental responsibility, as well as those under $\mathrm{s}$ 8 of the 1989 Act, may also prove problematic, since it must follow that "involvement" can mean mere possession of parental responsibility (that is, the involvement which applicants for parental responsibility will be seeking) ${ }^{28}$ It is difficult to see, therefore, how any applicant for a child arrangements order who already has parental responsibility for a child could fail to be deemed to be worthy of "involvement" with the child.

One particularly thorny issue of interpretation is likely to be how the presumption can be reconciled with the paramountcy of the child's welfare as set out in s 1(1) of the 1989 Act. Ryder J (now Ryder LJ), giving evidence to the Justice Committee, commented that the new provision could be interpreted as a general imperative rather than a presumption, highlighting what judges already believe is good practice, subject to the overarching principle of the welfare of the child. ${ }^{29}$ It is submitted that this view is not easy to sustain given the express wording that the court is "to presume, unless the contrary is shown, that involvement of that parent in the life of the child

26 For example, in s 13 of the Children Act 1989 (UK) where it is all important to know whether a primary carer of a child does, or does not, require the permission of the other parent or the court in order to take the child on a short holiday abroad for up to one month.

27 Andrew Bainham and Stephen Gilmore Children: The Modern Law (4th ed, Jordan Publishing, Bristol, 2013) at 243; and Stephen Gilmore and Lisa Glennon Hayes and Williams' Family Law (4th ed, Oxford University Press, Oxford, 2014) at 482.

28 The only definition of "involvement" is in s 1(2B) which provides that "'involvement' means involvement of some kind, either direct or indirect, but not any particular division of a child's time".

29 Justice Committee, above n 7, at [159]. 
concerned will further the child's welfare". ${ }^{30}$ Thus what s 11 of the 2014 Act enacts is truly a presumption, introducing an onus of contrary proof. The provision is impossible to reconcile with the view of Munby LJ (now the President of the Family Division) in Re F (Relocation) that there "can be no presumptions in a case governed by s 1 of the Children Act 1989". ${ }^{31}$ This is of course because the welfare principle requires a court to consider all the circumstances bearing on welfare, rather than the basic facts of a presumption simply prevailing in the absence of evidence to the contrary. A concern, given the focus on parental involvement, is that the presumption may run the risk in some cases that the welfare of the child will be subordinate to parents' interests.

As Thorpe LJ cautioned in Re L (A Child) (Contact: Domestic Violence), there: ${ }^{32}$

$\ldots$ is a danger that the identification of a presumption will inhibit or distort the rigorous search for the

welfare solution. There is also the danger that a presumption may be used as an aid to determination

when the individual advocate or judge feels either undecided or overwhelmed.

\section{Ideologically driven not evidence-based}

The introduction of a presumption of parental involvement is also questionable given the social science research evidence concerning the connection between child well-being and post-separation parenting arrangements, and the existing case law.

Reviews of the research evidence on the connection between contact arrangements and child well-being show that "it is not contact per se but the nature and quality of contact that are important to children's adjustment". ${ }^{33}$ Quality may depend on a range of factors, such as parents' relationships and the personalities of those involved, and there is a robust body of research connecting high interparental conflict with deleterious effects on child well-being. ${ }^{34}$ This complexity and the dangers of conflict do not advocate reliance in legal decision making on generalisations, but rather a careful consideration of the circumstances of each disputed contact case.

30 Children Act 1989 (UK), s 1(2A) (emphasis added).

31 Re F (Relocation) [2012] EWCA Civ 1364, [2013] 1 FLR 645 at [37].

$32 \operatorname{Re} L$ (A Child) (Contact: Domestic Violence) [2001] Fam 260 (CA) at 295.

33 Stephen Gilmore "Contact/Shared Residence and Child Well-being: Research Evidence and its Implications for Legal Decision-Making" (2006) 20 IJLPF 344 at 358. See also Judy Dunn "Annotation: Children's relationships with their non-resident fathers" (2004) 45 Journal of Child Psychology and Psychiatry 659; and Joan Hunt with Ceridwen Roberts Child Contact with Non-resident Parents (University of Oxford, Family Policy Briefing 3, 2004). For the perspectives of children recounted in later life as adults, see Jane Fortin, Joan Hunt and Lesley Scanlan Taking a longer view of contact: The perspectives of young adults who experienced parental separation in their youth (Sussex Law School, November 2012).

34 See for example Gordon T Harold and Mervyn Murch "Inter-parental conflict and children's adaptation to separation and divorce: theory, research and implications for family law, practice and policy" (2005) 17 CFLQ 185. 
Research on shared residence arrangements ${ }^{35}$ similarly shows that child well-being is most strongly connected to the quality of parenting rather than the particular form of post-separation parenting arrangement. ${ }^{36}$ Where shared residence is practicable, success tends to reflect parenting styles that are "child-focused, flexible, and cooperative", ${ }^{37}$ features not typically exemplified by parents who are fighting over shared residence in the courts. Sometimes shared residence arrangements can be experienced by children as burdensome, ${ }^{38}$ particularly when they are rigid. ${ }^{39}$ High levels of parental conflict are a particular risk factor for children in shared care arrangements, who can feel particularly exposed to, and caught between, their parents' conflict. ${ }^{40}$ There is also some evidence that overnight shared care of children under four years of age may be a risk factor for children's disrupted attachments and consequent behavioural problems. ${ }^{41}$ Thus the research on shared residence similarly advocates a careful focus on the individual case.

Case law already recognises that contact between parent and child is a fundamental element of the right to respect for family life within art 8 of the European Convention on Human Rights (ECHR),${ }^{42}$ placing a positive obligation on the state to maintain or restore contact. ${ }^{43}$ Contact is seen

35 For reviews and discussion of the research, see Fehlberg and others, above n 11; and Liz Trinder" Shared residence: a review of recent research evidence" (2010) 22 CFLQ 475.

36 Trinder, above $\mathrm{n} 35$, at 488 .

37 Fehlberg and others, above n 11, at 321-322.

38 See for example Carol Smart "From Children's Shoes to Children's Voices" (2002) 40 Family Court Review 307; Gry Mette D Haugen "Children's Perspectives on Everyday Experiences of Shared Residence" (2010) 24 Children and Society 112; and J Cashmore and others Shared Care Parenting Arrangements since the 2006 Family Law Reforms: Report for Australian Government Attorney-General's Department (Social Policy Research Centre, University of New South Wales, May 2010).

39 Jennifer McIntosh and others Post-separation parenting arrangements and developmental outcomes for infants and children: Collected reports (Attorney-General's Department, May 2010) at 47-49.

40 McIntosh and others, above n 39; and for discussion, see Jennifer McIntosh and Richard Chisholm "Cautionary notes on the shared care of children in conflicted parental separation" (2008) 14 Journal of Family Studies 37; Christy M Buchanan, Eleanor E Maccoby and Sanford M Dornbusch "Caught between Parents: Adolescents' Experience in Divorced Homes" (1991) 62 Child Development 1008; and Christy M Buchanan, Eleanor E Maccoby and Sanford M Dornbusch Adolescents After Divorce (Harvard University Press, Cambridge (Mass), 1996).

41 McIntosh and others, above n 39, at 9.

42 Convention for the Protection of Human Rights and Fundamental Freedoms 213 UNTS 221 (opened for signature 4 November 1950, entered into force 3 September 1953), art 8. See also art 9(3) of the Convention on the Rights of the Child 1577 UNTS 3 (opened for signature 20 November 1989, entered into force 2 September 1990) [UNCRC], which enjoins States Parties to "respect the right of the child who is separated from one or both parents to maintain personal relations and direct contact with both parents on a regular basis, except if it is contrary to the child's best interests"; and arts 7, 8, 9 and 18(1) of the UNCRC, which are usefully identified and discussed in Andrew Bainham "Contact as a Right and Obligation" in Andrew Bainham and others (eds) Children and Their Families: Contact, Rights and Welfare (Hart Publishing, Oxford, 2003) 62. 
as almost always in the interests of the child, ${ }^{44}$ or put another way, the court applies the welfare principle to the facts of a case from the general assumption that contact is beneficial, ${ }^{45}$ and contact will only be denied if detrimental to the child's welfare. Thus the new presumption does not in substance remedy any existing mischief in the law. ${ }^{46}$ The point should also be made that "involvement" of both parents, in terms of having a say in the child's life, has always continued despite parental separation, at least in law, because this is a matter of parental responsibility which both retain. This has been so ever since the enactment of the 1989 Act but has very arguably not been well enough appreciated by the public at large. The assumption often made that some court order, especially for shared residence, has been required to ensure participation in issues affecting the child has always been erroneous. It may be that this problem could have been ameliorated if Parliament had expressly stated this in the legislation rather than leaving it to implication from the rather obscure cluster of subsections in s 2 of the 1989 Act. ${ }^{47}$ Had this been done, the current perceived need for a presumption of parental involvement might have been lessened or even removed altogether.

Indeed, the Government acknowledged in its consultation document that the benefit of ongoing involvement with both parents is already factored into court decisions. The Government's concern was that it was "not explicitly stated in the legislation that guides this process" and that this had "contributed to a perception that the law does not fully recognise the important role that both parents can play in a child's life". ${ }^{48}$ The aim of the provision was said to be "to reinforce the expectation at societal level that both parents are jointly responsible for their children's upbringing"49 and to "send a clear signal to separated parents". ${ }^{50}$ As Trinder observes, the period of policy debate since 2012 can be characterised as one in which symbolism has come to the fore. ${ }^{51}$

In the authors' opinion, there is no doubt that enactment of the new provisions was ideologically driven rather than representing a genuine evidence-based desire to change the substantive nature of court orders and court decision making.

43 The principles are neatly summarised in Re C (Direct Contact: Suspension) [2011] EWCA Civ 521, [2011] 2 FLR 912 at [37]-[47].

44 See for example Re O (Contact: Imposition of Conditions) [1995] 2 FLR 124 (CA) at 128.

$45 \operatorname{Re} L$ (A Child) (Contact: Domestic Violence), above n 32.

46 A point made by Matthew O'Grady "Shared parenting: keeping welfare paramount by learning from mistakes" [2013] Fam Law (April) 448.

47 Section 2(5), (6) and (7).

48 Department for Education, above n 14, at [3.1].

49 At [3.2].

50 At [4.3].

51 Trinder, above n 5. 
The political resolve to achieve desired reform can arguably be seen in the manner in which the consultation process with regard to the presumption of parental involvement was framed and reported, which seemed determined to elicit a positive response to the Government's preferred option. First, the analysis did not distinguish in the weight given between individual responses, and responses by charities, practitioner, policy or other groups, which of course were representing particular knowledge/expertise, and in many cases more than an individual viewpoint. ${ }^{52}$ Secondly, the consultation was on proposed legislative options, so there was no option of "no change". Thirdly, percentages cited were percentages of respondents to individual questions rather than of respondents to the consultation as a whole; an approach which was favourable to the Government's case. The views of those who refused or failed to answer a question, perhaps because they did not favour any option, were thus not (fully) factored in.

As the following brief analysis will show, it is possible that if all responses were factored in, the Government's option would not have elicited a majority percentage in favour. There were 214 responses to the consultation overall, of which, we are told, 53 (25 per cent) stated that they did not agree with any form of legislation. Of the 181 responses to the question which legislative approach would be most effective in meeting the Government's stated objectives, 93 ( 52 per cent) favoured the Government's option, 66 (36 per cent) selected another option and 22 (12 per cent) made no selection. It seems unlikely, however, that the 53 who opposed legislation would select an option. If, for example, only the 22 who made no selection were members of the 53 who stated they did not agree with any form of legislation, there would still remain 31 non-responses to the question (53 minus 22) who are known to oppose any legislation, and who arguably could also be counted as making no selection. On that basis there would be 212 answers to the question and only 44 per cent in favour of the Government's option. ${ }^{53}$

In addition, Felicity Kaganas' detailed analysis of the messages emanating from the debates leading up to enactment identifies the presumption's largely symbolic function, of restoring the status of fathers and confidence in a much-criticised family justice system. ${ }^{54}$ Indeed, the Justice

52 A point made in Justice Committee, above n 7, at [143]. The breakdown of respondents was as follows: father (67); voluntary and community sector (35); academic/researcher (22); mother (18); grandparent/other family member (17); judge/magistrate (11); mediator (11); barrister (5); solicitor (8); and other (20).

53 The Government's portrayal of the strength of support for its option sits rather uneasily with the fact that 56 per cent of respondents ( 94 out of 167 responses) were "concerned that legislative change could lead to an expectation of 50/50 share of the child's time between parents - which could potentially put a child at risk of emotional or physical abuse where there was ongoing conflict". Furthermore, opinion was divided on whether legislation would encourage parents to resolve disputes out of court (of 169 responses, 43 per cent yes, 65 per cent no, 19 per cent not sure). Of 175 respondents, more felt that legislation would increase litigation (40 per cent) than decrease it (29 per cent). (Others were either not sure (17 per cent) or thought there would be "no change" (14 per cent).)

54 Felicity Kaganas "A presumption that 'involvement' of both parents is best: deciphering law's messages" (2013) 25 CFLQ 270. 
Committee's analysis of the relevant Minister's responses at the stage of pre-legislative scrutiny of the presumption ${ }^{55}$ concluded $^{56}$ that its aim was "not to effect any change in Court orders but to tackle a perception of bias within the Courts", which moreover the Committee had "previously concluded has no basis in fact". ${ }^{57}$ As the Law Society of England and Wales commented, the provision was driven by the political reality of Ministers' "wish to be seen to be responding to the concerns expressed by fathers' and other groups. ${ }^{58}$

\section{THE PUBLIC LAW}

The public law provisions in pt II cannot be properly understood in isolation from the ragbag of apparently disconnected adoption provisions in pt I. Perhaps one of the reasons why, in England and elsewhere, the place of adoption as a child protection mechanism is often misunderstood and misjudged, is because of the tendency to enact separate adoption statutes on the back of separate considerations by government and law reform agencies. ${ }^{59}$ This creates the impression that adoption is somehow detached, or even irrelevant, to the main body of children legislation as opposed to an integral part of it. We see this phenomenon once again in the 2014 Act.

Having said that the adoption provisions in pt I should not be divorced from the public law provisions of pt II, we have to start somewhere. The logical place to start is with the latter because, as everyone knows, care precedes adoption in the child protection process.

The relevant provisions are ss 13,14 and 15 relating respectively to the control of expert evidence and assessments, time limits and the role of the court in relation to care plans. Of these, it is the issue of time limits which has perhaps evoked the greatest debate in the family law community.

\section{A Delay and the Time Factor in Family Proceedings}

The key problem in the public law, identified by the Family Justice Review and accepted by the Government, was delay. Figures cited by the Family Justice Review showed that cases in the county

55 Including the following statements: "The intention ... is to deal with the sense that there is an in-built bias towards one parent or another within the current system, to get more confidence into that system with those who come into contact with it ... The most important element of this is to ensure that there is real confidence in those who come into contact with it ... The most important element of this is to ensure that there is real confidence in the family justice system."

56 Justice Committee, above n 7, at [153].

57 See Justice Committee, above n 8, at [65].

58 Law Society of England and Wales Co-operative parenting consultation response (September 2012).

59 Thus adoption fell outside the root and branch reforms of children law by the Children Act 1989 (UK), continuing to be governed by its own legislation, the Adoption Act 1976 (UK). In 2002 it was again thought appropriate to reform adoption law as a self-contained area of law in the Adoption and Children Act 2002 (UK). 
court were taking on average 61 weeks, while those in the magistrates' family proceedings courts were taking 48 weeks, despite a target of 40 weeks having been set. ${ }^{60}$

The problem of delay in children cases in not a new one. The "no delay" principle was an innovation of the 1989 Act $^{61}$ which followed separate reviews of the private and public law. The perception at that time was that delay was a more pressing problem in the private law, ${ }^{62}$ rather contrary to the current emphasis on - some would say obsession with - the issue in the public law. In so far as the Review of Child Care Law considered delay at all, it was largely in the context of the length of interim orders. ${ }^{63}$ That Review did conclude that "further consideration should be given to prescribing maximum time limits in care proceedings ... and whether delay continues to be a problem in care proceedings. "64 But that was as far as it went.

The 2014 Act amends the 1989 Act and puts on a statutory footing a very much more restrictive time limit of 26 weeks, from the issue of proceedings to their conclusion. ${ }^{65}$ This is a mandatory time limit which can be extended only with the permission of the court. Permission can be given only if the court considers it necessary to enable it to resolve the proceedings justly. ${ }^{66}$ It is expressly provided that such extensions will not be granted routinely and will require "special justification". ${ }^{67}$ Where given, an extension must not exceed eight weeks. ${ }^{68}$

These stringent statutory limits are backed up by the Family Procedure Rules and the Revised Public Law Outline. ${ }^{69}$ They have provoked serious concerns about whether the best interests of the child can be confidently established within so short a period of time, where what is at issue is usually parental capacity to provide adequate care and to change for the better. This is a feature of the many cases in which substance abuse is a major factor, and in which the parents' willingness and

60 Family Justice Review: Final Report, above n 4, at [3.2].

61 Children Act 1989 (UK), s 1(2) provides: "In any proceedings in which any question with respect to the upbringing of a child arises, the court shall have regard to the general principle that any delay in determining the question is likely to prejudice the welfare of the child."

62 See Law Commission of England and Wales Review of Child Law: Guardianship and Custody (Rep No $172,1988)$ at $[4.54]$ and following.

63 Department of Health and Social Security Review of Child Care Law: Report to Ministers of an Interdepartmental Working Party (HMSO, 1985).

64 At [17.25]

65 Children Act 1989 (UK), s 32(1) as amended by Children and Families Act 2014 (UK), s 14.

66 Section 32(5).

67 Section 32(7).

68 Section 32(8).

69 Family Procedure Rules 2010 and Practice Direction 12A. 
ability to abstain will need to be tested over time. ${ }^{70}$ It must also be questioned how far the concept of proceedings being concluded "justly" involves justice, not only to the child but also to the parents.

Legitimate concerns also exist in relation to the early stages of public law proceedings and the critical question of removal of children under interim care orders. The new procedures have effectively dispensed with what used to be the first hearing in care proceedings. ${ }^{71}$ In the light of the requirements now imposed in relation to pre-proceedings work, when the matter comes to court for the first time the norm will now be for a case management hearing $(\mathrm{CMH})$. Such a hearing must be listed within 12 to 18 days of the issue of proceedings. ${ }^{72}$ Before this, the court will consider any request for the listing of an urgent hearing, which could be a hearing to consider an urgent contested interim care order. But any such hearing is not to result in delaying the $\mathrm{CMH}$. The concern here is that the issue of the child's interim placement may be rushed and may not receive the careful consideration it has traditionally received. Where the child's removal under an interim care order was proposed, if contested, this would normally have required listing the case for at least one day and possibly longer. This would give the parents a proper opportunity to respond formally to the local authority's initial evidence and for that evidence to be tested in court. But now such a hearing is described as "urgent" and will take place only "if required". ${ }^{73}$ There is certainly anecdotal evidence that children are now being removed after limited hearings on the basis of the authority's written evidence and advocates' submissions, and that this is becoming more commonplace. Yet it is surely questionable whether (other than in clear emergencies) any child should be removed into care without the parents having an opportunity to test the evidence in cross-examination, and indeed whether this complies with the human rights of both parents and child. But in the new world in which time limits and case management take centre stage, the danger is that full interim hearings are seen as an unaffordable luxury.

In care proceedings, which may result in one of the most draconian orders which can be made under the legal system, it can be of great importance to parents that matters are not rushed. The issuing of proceedings will come as a severe shock to most of them and the great majority will not accept at the start that they lack the ability to look after their children. It is only after measured

70 A specialist Family Drugs and Alcohol Court (FDAC) has been pioneered in London in an attempt to deal more effectively and efficiently with this phenomenon. For an excellent discussion of the work of FDAC see Judith Harwin and others "Strengthening prospects for safe and lasting family reunification: can a Family Drug and Alcohol Court make a contribution?" (2014) 35 JSWFL 459.

71 Under the revised Public Law Outline in Practice Direction 12A, the first stage is now normally for issue and allocation which includes listing the case management hearing.

72 Stage 2 of the revised Public Law Outline.

73 Under the Family Procedure Rules 2010, r 22.7, the general rule at hearings other than final hearings is that they are conducted on submissions, as opposed to oral evidence, unless the court directs otherwise or any practice direction or other enactment provides otherwise. 
expert assessment, proper investigation of all the family options and sound legal advice that a parent may reach the sad conclusion that he or she is not up to the task and that an alternative must be found. The function of the proceedings is then in part to allow sufficient time for parents to come to terms with the situation. If this process is concertinaed, the result is likely to be more heavily contested hearings and less acceptance by parents of the ultimate determination of the court. The Family Justice Review acknowledged this problem but only in the context of the need to provide parents with support post-proceedings. ${ }^{74}$

It is also questionable whether the imposition of rigid time limits reflects a sufficient understanding of the role of time and the time factor in family proceedings, or of the organic nature of such proceedings. Unlike many areas of the law in which there is essentially a forensic enquiry into what happened in the past, family proceedings take place in the shadow of ongoing family life. The parents' situation, that of the wider family and that of the children concerned, may and often do change dramatically during the course of the proceedings. It is therefore an impossible task to say at the start how long it is going to take to reach a proper determination of what is best for a child. Attempts to set clear limits fly in the face of this. A better focus would arguably have been on identifying and dealing with delays which are the result of incompetence and those which are not. The concept of "purposeful delay"75 insufficiently captures the essence of family proceedings. They are not so much about careful planning as about an appropriate reaction to events. The judicial function of "robust case management", currently in vogue, must surely take second place to the judge's duty to achieve the right result for the child. The better judges will readily admit this inside and outside court. The danger is that we may be promoting a culture of deciding in haste and repenting at leisure.

Perhaps the most fundamental concern about time limits is that the no delay principle is now in danger of supplanting in importance the welfare principle. The reforms are capable of giving the impression that the paramount consideration or - to put it more neutrally - the key objective, is now completing the case on time rather than achieving the result which is right for the child. This was certainly not the intention of those who drafted the 1989 Act. There was no sense at all at that time that the issue of delay was to be given the level of prominence which this legislation gives to it.

\section{B Expert Evidence and Assessments}

Section 13 of the 2014 Act and the Family Procedure Rules provide that any party wishing to instruct an expert must obtain the permission of the court. Essentially the same test applies as that governing extension of time limits. The instruction of the expert must be necessary to assist the

74 Family Justice Review: Final Report, above n 4, at [3.185].

75 A concept which has its origins in a Law Commission Report, where the Commission gave the example where waiting for a thorough welfare report might outweigh the disadvantages to the child of delay: Law Commission of England and Wales, above n 62, at [4.57]. 
court to resolve the proceedings justly. ${ }^{76} \mathrm{~A}$ similar requirement is imposed in relation to interim assessments of the child. ${ }^{77} \mathrm{~A}$ range of factors is prescribed which the court must take into account when deciding whether to grant permission. ${ }^{78}$

These provisions do have laudable objectives in seeking to combat the problem of "expertitis" or the multiplication of experts in care proceedings. The point is well made that in some cases there was unnecessary duplication of expertise where, for example, there may have been both psychiatric and psychological reports, parenting assessments by local authority and independent social workers, as well as successive analyses and recommendations by the guardian. This may have been accompanied by successive and expensive scientific tests, not always sufficiently focused, for substance abuse by parents. The cost to the legal aid fund could in some cases be enormous, some of the ground was undoubtedly covered twice and delays were a regular occurrence while waiting for one or more expert reports to be made available.

Notwithstanding these legitimate concerns, the anxiety now is that we have moved too far in the opposite direction. Two factors in the statutory list, apparently innocuous in their wording, have the potential for denying the admission of expert evidence where it is necessary. It is provided that the court is to have regard to "what other evidence is available" and "whether evidence could be given by another person on the matters on which the expert would give evidence" ${ }^{79}$ The implication of these factors is not simply that one expert may do where previously there may have been two, but that the evidence of two of the parties to the proceedings, the local authority and the guardian, may be good enough. This is an approach which appears to have received some endorsement by Pauffley $\mathrm{J}$ in Re MR (Welfare Hearing No 2). ${ }^{80}$

The chief criticism is that it attaches far too little importance to independence in expert evidence. However capable and well-intentioned the allocated social worker is, there will be an acute perception (sometimes accurate) on the part of the parent that he or she is not neutral. The social worker will have produced the key evidence in support of the care application and is the local authority's key witness in the courtroom. Parenting assessments produced by the allocated social worker are therefore at best not likely to be seen as detached or independent. At worst they will be viewed as produced by the very person who is seeking to remove the children and has caused the

76 Children and Families Act 2014 (UK), s 13(6).

77 Section 13(11).

78 Section 13(7).

79 Section 13(7)(d) and (e).

80 Re MR (Welfare Hearing No 2) [2013] EWHC 1156 (Fam), (2013) Fam Law 939 where she said that the local authority social worker and the guardian might not be "experts" in the technical sense but that they had provided the court with all the assistance it required to perform its tasks justly. That may be so in a strong case on its facts, as this case appears to have been, but there are dangers in taking this principle too far. 
proceedings to be instigated in the first place. In many cases, the allocated social worker will be seen by parents as having already taken a view (often adverse to them). It is worth remembering the comments of Wall LJ in Re EH in this respect. ${ }^{81}$ It is perfectly fair to say that this problem is ameliorated where a different team from within the local authority is responsible for producing the parenting assessment. But the underlying problem of being independent and seen to be independent remains. Further problems arise because the local authority's own resources are often just too stretched to devote sufficient time to an in-depth parenting assessment. This is a point which can be equally well made in relation to guardians whose primary function is in any event to focus on and represent the child in the proceedings. It is not the role of guardians to act as neutral experts on parenting abilities and many issues, for example psychiatric or psychological issues, will be outside their area of expertise.

We need to get back to a clear understanding that at least some genuinely independent expert evidence should be put before the court, especially where long-term removal of the child into care outside the family is proposed.

\section{Scrutiny of Care Plans}

When the last reform of adoption law took place in 2002, that legislation put care plans on a statutory footing for the first time. The local authority must now always prepare and keep under review a care plan for the child in every case in which it has made an application which could result in a care order being made. ${ }^{82}$

Before the 2014 amendments, the court was under an obligation to consider the care plan before making a care order. The court had no power to direct the local authority about what should be in its care plan, but it had the ultimate sanction at its disposal of refusing to make a final care order until satisfied with the provisions in the plan. In that indirect way the court, often prompted by concerns raised by the children's guardian, could influence the care plan and the detailed provisions in it. One senior Judge, who heard a great many care cases, considered that courts did not abuse this power to scrutinise the care plan during care proceedings and that constructive changes to care plans were often made. ${ }^{83}$

81 In EH v Greenwich LBC [2010] EWCA Civ 344, [2010] 2 FCR 106, he famously said at [109]: "What social workers do not appear to understand is that the public perception of their role in care proceedings is not a happy one. They are perceived by many as the arrogant and enthusiastic removers of children from their parents into an unsatisfactory care system, and as trampling on the rights of parents and children in the process."

82 Children Act 1989 (UK), s 31(3)A, as inserted by the Adoption and Children Act 2002 (UK).

83 District Judge Nicholas Crichton, "Comment: The Family Justice Review" [2012] Fam Law 3. 
The 2014 Act curtails this judicial function, ${ }^{84}$ again with the objective of streamlining proceedings and reducing delays, by confining the scrutiny of the court to the "permanence provisions" in the care plan. ${ }^{85}$ These are essentially the three options of: (a) placement with a parent or kinship care in the wider family or with friends; (b) adoption; or (c) other long-term care (effectively long-term foster care or, in a small minority of cases, institutional care). ${ }^{86}$

The concern again here is that this is cutting corners at the expense of the best interests of the child. In essence the new provisions mean that the court is not to concern itself with the detailed content of care plans. But can local authorities be trusted to get the detail right? The devil is often in the detail of care plans and it is not uncommon for authorities to resist any changes to them which are liable to involve expenditure. Care plans and written agreements with parents, which can be an integral part of care plans, often spell out in some detail the obligations of parents and what is expected of them. But they are often light on the support package being offered to parents, and the extent of the authority's own obligations, where cases end with a supervision order and children at home. Care plans frequently provide for less contact than parents and members of the wider family would wish to have with children who, under the plan, are to remain in long-term foster care. It is important that these and many other matters of detail should be under the scrutiny of the court, with the benefit of the input of the guardian, but the reforms at best discourage this involvement and at worst prohibit it.

\section{The Adoption Provisions}

The provisions which directly affect adoption are clustered together in pt I of the 2014 Act. Two provisions which deal with the issue of contact between children and parents in the public law context appear sequentially in ss 8 and 9, reflecting rather well the point that parents' contact with children in care and post-adoption contact are indeed closely related. In one sense they are the same issue at different points along the child protection spectrum.

So far as these contact provisions are concerned, the policy of the 2014 Act, whether during care proceedings or post adoption, is to continue (as indeed the law must) to make provision for such contact. But equally the policy is to discourage it and allow for a judicial order prohibiting contact where necessary to safeguard or promote the welfare of the child. Where the child is in care there is

84 But note the recent case of Re E (A Child) (Care Order: Change of Care Plan) [2014] EWFC 6, [2015] Fam 145 , in which Baker $\mathrm{J}$ sets out guidance, agreed by the President of the Family Division, on when a child may be removed from parents pending a change in the care plan which is contested. Such a change requires proper consideration by the court of the available evidence. In other words, the court must scrutinise the evidence supporting a change in the care plan where this would lead to removal of the child. In this case the child had, unusually, been living with the parents at home under a final care order for a period of 18 months.

85 Children Act 1989 (UK), s 31(3A).

86 Section $31(3 \mathrm{~B})$. 
a statutory presumption of reasonable contact between the child, the parents and certain others. ${ }^{87}$ But the local authority may refuse such contact for up to seven days in urgent cases, ${ }^{88}$ and the court may make an order authorising a denial of contact. ${ }^{89}$ These provisions sound innocuous and evenhanded, but the 2014 legislation has now amended the 1989 Act in a way which is designed to tilt the balance towards restrictions on contact. The cynic may say that the purpose is again to streamline care proceedings and push children through them quickly. This objective is not assisted by the inconvenience of having to allow contact between children and parents where the authority is clearly of the view that they do not support reunification. The legislation now makes it explicit that the normal statutory duty to endeavour to promote contact does not apply where contact has been refused under the above provisions. ${ }^{90}$

A similar emphasis is given to the issue of post-adoption contact, though we should note that the 2014 Act leaves largely untouched the arguably more important provisions in the adoption legislation governing contact at the time of making a placement order or under placement, but before adoption proceedings. ${ }^{91}$ The 2014 Act amends the Adoption and Children Act 2002 (UK) to create a new statutory regime governing post-adoption contact. ${ }^{92}$ The provisions have an initial appearance of neutrality on the issue. On a closer inspection however, the contact regime is not neutral. It leans towards discouragement of such contact. Thus, while the court may make an order for contact or an order prohibiting it, the child or the adopters/prospective adopters may apply as of right, while parents and others require the leave of the court. ${ }^{93}$ Moreover, while an order providing for contact may only be made on application, an order prohibiting it may be made of the court's own volition. ${ }^{94}$ The message is clear. There are significant hurdles to be surmounted where contact is sought, which do not have to be crossed in order to get it prohibited. It is evident that this will facilitate applications by prospective adopters who are opposed to contact, especially direct contact,

87 Children Act 1989 (UK), s 34(1).

88 Section 34(6).

89 Section 34(4).

90 Section 34(6A), as amended by Children and Families Act 2014 (UK), s 8.

91 Adoption and Children Act 2002 (UK), s 26. This provision is arguably more important than provisions for post-adoption contact because, realistically, if direct contact is to be maintained between a parent and a child authorised to be placed for adoption, it really needs to the subject of an order at the time the placement order is made. Such orders are likely to be hotly resisted because their effect may be to reduce greatly the pool of prospective adopters or even drain it completely. But if ongoing contact between the child and the birth family is deemed to be in the child's best interests, it needs to be secured, either by declining to make a placement order at all or, if making one, making it with an accompanying contact order.

92 Section 51A, as inserted by Children and Families Act 2014 (UK), s 9.

93 Section $51 \mathrm{~A}(4)$.

94 Section $51 \mathrm{~A}(6)$. 
with the child's birth family. It is a further example of the deference already shown to their views on the issue of contact which is a feature of the jurisprudence in this field. ${ }^{95}$

The other adoption provisions in the 2014 Act are unashamedly about promoting adoption as a preferred child protection mechanism for the long-term care of children. ${ }^{96}$ This follows the Narey Report and the Government's action plan, ${ }^{97}$ which largely gave its support to what Narey proposed. Thus, the local authority is now to be under a statutory obligation to consider placing the child in a "fostering for adoption placement", viz with foster parents who have been approved as prospective adopters. ${ }^{98}$ The intention is clearly that it may then be that much easier to move quickly on to adoption if that is the ultimate decision of the court. Likewise there is repeal of the so-called "ethnicity provision" which required the adoption agency, in placing a child for adoption, to give due consideration to the child's "religious persuasion, racial origin and cultural and linguistic background". ${ }^{99}$ It was thought that this explicit reference to ethnicity was again slowing down the pace of adoptions involving ethnic minority children, and that the general provision in the legislation making reference to the child's "particular needs", "age, sex, background" and other relevant characteristics ${ }^{100}$ was adequate. Other provisions encourage the recruitment of prospective adopters and the further development of adoption support services. ${ }^{101}$

\section{E On a Collision Course with Human Rights?}

These legislative developments are taking place at the very moment that the higher courts have chosen to assert themselves over compliance with human rights requirements in the public law and adoption context. The landmark cases are $\operatorname{Re} B$ in the Supreme Court ${ }^{102}$ and $R e B-S$ in the Court of Appeal. ${ }^{103}$ Extensive satellite jurisprudence has grown up around these decisions, focusing in

95 See particularly $\operatorname{Re} R$ (A Child) (Adoption: Contact) [2005] EWCA Civ 1128, [2006] 1 FLR 373; and Re J (A Child) (Adopted Child: Consent) [2010] EWCA Civ 581, [2011] Fam 31. Contrast with MF v London Borough of Brent [2013] EWHC 1838 (Fam), [2014] 1 FLR 195.

96 Though a provision facilitating contact between relatives of a person adopted before 2005 (when the 2002 Act came into force) and that person's birth relatives was a late parliamentary addition which bizarrely became s 1 of the 2014 Act. It is noteworthy as the only provision in pt I which is clearly supportive of open adoption, albeit in the rather limited context of facilitating contact between adoptive and birth relatives where an adopted person has died.

97 Department of Education An Action Plan for Adoption: Tackling Delay (2011).

98 Children Act 1989 (UK), s 22 C as amended by Children and Families Act 2014 (UK), s 2.

99 Adoption and Children Act 2002 (UK), s 1(5), as amended by Children and Families Act 2014 (UK), s 3.

100 Adoption and Children Act 2002 (UK), s 1(4).

101 Children and Families Act 2014 (UK), ss 4-7, making relevant amendments to the Adoption and Children Act 2002 (UK).

102 Re B (Care Proceedings: Threshold Criteria) [2013] UKSC 33, [2013] 1 WLR 1911.

103 Re B-S (Adoption Order: Leave to Oppose) [2013] EWCA Civ 1146, [2014] 1 WLR 563. 
particular on the procedural and evidential requirements imposed by Re B-S. ${ }^{104}$ In essence what the higher courts have said is that in order to comply with the requirements of the ECHR, adoption must be viewed as a "last resort" when all else has failed. Before making a final care order or placement order, the court must look at all realistic options holistically, as opposed to sequentially, and all decisions must be properly evidenced and properly reasoned. It is no longer permissible to "pick off" or "rule out" parents or other proposed carers during the interim phases of care proceedings, leaving adoption as the "last man standing". It is clearly doubtful whether a decision favouring adoption just because that appears to be the preferred solution, applying a welfare criterion, will be lawful any longer. There has been a deluge of appeals to the Court of Appeal where the Court, faced with many cases in which the reasoning of the court was not $\operatorname{Re} B$-S compliant, has had to consider whether the judge in the lower court engaged with the essence of the balancing exercise requiring comparative consideration of all realistic options for the child. ${ }^{105}$ Whether or not the approach of the 2014 amendments is reconcilable with the human rights obligations insisted upon by the courts is now a fertile area of academic debate.

What is surely clear beyond doubt is that the ethos or emphasis of these two developments is quite different. The 2014 reforms have a distinctly American flavour about them and are reminiscent of the philosophical shift which took place in the United States with the enactment of the federal Adoption and Safe Families Act in $1997 .{ }^{106}$ In contrast, the underlying ethos of the ECHR and the recent decisions of the courts is an attempt to achieve reunification of parent and child. Although understood to be a central aim of the 1989 Act, nowhere is this principle expressly stated in that legislation. It is perhaps this lacuna which in part has allowed the 1989 Act to be amended in a way which is certainly not supportive of the notion that reunification is centre stage in child protection proceedings. When adoption legislation was reformed a decade or so ago, there were those who pointed out that much of the world does not subscribe to the idea that compulsory adoption is even permissible, let alone a proper preference. ${ }^{107}$ In many jurisdictions, there is a much greater willingness to work towards reunification with parents, or to promote kinship care, as indeed is the tradition in New Zealand. The pejorative, second-class image which we have of foster care in

104 For an assessment by one of the authors of some of this case law, see Andrew Bainham and Hannah Markham "Living with $\operatorname{Re} B-S$ : Re $S$ and its implications for parents, local authorities and the courts" [2014] Fam Law 991.

105 The test to be applied to pre-Re B-S decisions of the lower courts as held in Re W (Adoption Order: Leave to Oppose) [2013] EWCA Civ 1177, [2014] 1 WLR 1993.

106 See Barbara Bennett Woodhouse "The United States: The Adoption and Safe Families Act: A major shift in child welfare law and policy" in Andrew Bainham (ed) International Survey of Family Law (Jordan Publishing, Bristol, 2000) 376.

107 See especially the comparative study, A Warman and C Roberts Adoption and Looked After Children: International Comparisons (Oxford Centre for Family Law and Policy, 2003). 
England is not shared by others. ${ }^{108}$ It is clearly an area in which work is required in England alongside a more proactive promotion of the institution of special guardianship.

This drama continues to be played out and, at the time of writing, it is by no means clear how far the courts will allow challenges to the provisions of the 2014 Act on the basis that they do not comply with human rights.

\section{CONCLUSION}

The 2014 Act is arguably the most ideological piece of family legislation since the Family Law Act 1996 (UK). While that ill-fated legislation sought to discourage divorce by slowing the process down, the 2014 Act seeks to encourage adoption by speeding the process up. It is indeed ironic that the now infamous pt II of the Family Law Act 1996 (UK) was finally repealed by the 2014 Act some 18 years after its enactment. ${ }^{109}$

The essential thrust of pt I and the public law provisions of pt II is to get children through care proceedings as quickly as possible, out the other side and into adoptive families on the basis of a rather quick judgement that their parents cannot cope. There is no great enthusiasm, either, for kinship care in this legislation. Narey was notably scathing about what he saw as protracted and overdone investigations of family placements ${ }^{110}$ - an attitude which one suspects would go down extremely badly in New Zealand.

This apparent policy has however come into collision with a burgeoning jurisprudence in the higher courts. This jurisprudence cannot be interpreted as anything other than insisting on the need for serious scrutiny and great caution before a placement order for adoption is made at the conclusion of care proceedings. ${ }^{111}$ Anyone looking at these developments in juxtaposition might be forgiven for wondering whether, in England, adoption is now the first or last resort.

Within the private law we see again the influence of ideology and the importance attached to statutory language as a means of conveying an "official" message. Here the message is the importance of both separating parents remaining "involved" in the lives of their children. There is

108 Warman and Roberts drew attention particularly to attitudes in the Netherlands and Sweden, where longterm foster care has a much more positive image and is seen as (relatively unproblematically) inclusive of parental contact.

109 Children and Families Act 2014 (UK), s 18.

110 Narey, above n 3, at 11. Under the heading "Special Guardianship: An Unhappy Compromise" Narey quotes a senior official in the Department of Education as saying: "Special guardianship may simply mean that the child ends up in a different branch of an essentially dysfunctional family."

111 The leading cases being the Supreme Court's decision in Re B (Care Proceedings: Threshold Criteria), above n 102; and Re B-S (Adoption Order: Leave to Oppose), above n 103. But see more recently $\operatorname{Re} R(A$ Child) (Adoption: Judicial Approach) [2014] EWCA Civ 1625, [2015] 1 WLR 3237, in which the Court of Appeal may be viewed as having tempered the effect of these decisions. 
nothing new in this as an idea. One of the few worthwhile provisions in pt II of the Family Law Act 1996 (UK) had encapsulated the idea all those years ago. ${ }^{112}$ What is new is that, contrary to the steadfast refusal of the English courts to countenance any legal presumption as to the best interests of children, ${ }^{113}$ we now have one in the 2014 Act. This is a very definite break with tradition. It is supposedly buttressed by a more neutral "child arrangements order"114 to replace what is thought to have been the polarising duality of "residence" and "contact" orders, but which is little more than a change of terminology with the disadvantage of greater complexity.

A key question, cutting across both the private and public law provisions (including those relating to adoption), is whether the 2014 Act dilutes the long-standing commitment to the welfare or paramountcy principle. Critics may say that in the private law the new presumption of parental involvement does just that, and that in the public law the paramount consideration now seems to be not the welfare of children but the avoidance of delay at all costs.

112 One of the factors which the court was directed to have regard to in considering whether it should exercise its powers to make an order in relation to children on divorce was "the general principle that, in the absence of evidence to the contrary, the welfare of the child will be best served by- (i) his having regular contact with those who have parental responsibility for him and with other members of his family; and (ii) the maintenance of as good a continuing relationship with his parents as is possible": Family Law Act 1996 (UK), s 11(4)(c). It was also a general principle under that Act that those exercising functions under it should endeavour, inter alia, "to promote as good a continuing relationship between the parties and any children affected as is possible in the circumstances": Family Law Act 1996 (UK), s 1(c)(ii).

113 See particularly Brixey v Lynas [1996] 2 FLR 499 (HL); Re G (Children) (Residence: Same-sex Partner) [2006] UKHL 43, [2006] 1 WLR 2305; and Re B (A Child) (Residence: Biological Parent) [2009] UKSC 5, [2009] 1 WLR 2496.

114 Children Act 1989 (UK), s 8 as amended by Children and Families Act 2014 (UK), s 12. 